\title{
Assessing the Vulnerability of Public-Supply Wells to Contamination: Rio Grande Aquifer System in Albuquerque, New Mexico
}

The pathways and processes by which contaminants reach public-supply wells was intensively investigated during 2001-2012 in nine aquifer systems across the Nation as part of the U.S. Geological Survey's National Water-Quality Assessment (NAWQA) Program. Specifically, scientists studied the processes that occur below land surface - whereby contaminants are mobilized or attenuated - as well as investigated how human activities can affect the vulnerability of public-supply wells to contamination.

This fact sheet highlights findings from the vulnerability study of a public-supply well in Albuquerque, New Mexico (Bexfield and others, 2012; Heywood, in press). The well selected for study (hereafter referred to as "the study well”) typically produces about 3,000 gallons of water per minute from the Rio Grande aquifer system. In construction and operation, the study well is typical of many public-supply wells in the region (although not all wells in the region produce as much water as this well).

Untreated water samples collected at the study well between 2007 and 2009 contained some undesirable constituents, including contaminants that occur naturally and others that are anthropogenic (introduced by human activity). Arsenic, which occurs naturally in aquifer sediments, was found at concentrations ranging from 12 to 18 micrograms per liter $(\mu \mathrm{g} / \mathrm{L})$, exceeding the Maximum Contaminant Level (MCL) of $10 \mu \mathrm{g} / \mathrm{L}$ established by the U.S. Environmental Protection Agency for drinking water. Arsenic is of particular concern to water managers in this region because concentrations in groundwater exceed the MCL in broad areas in and near Albuquerque (Bexfield and Plummer, 2003). The water utility for Albuquerque and Bernalillo County began using low-arsenic surface water as a major source of drinking water in 2008 in response to declining water levels in the aquifer. Groundwater and surface water are now typically blended, which facilitates delivery to customers of water with arsenic concentrations below the MCL. The anthropogenic constituents trichloroethylene (TCE) and its degradation product $c i s-1,2-$ dichlorethylene, as well as methyl tertbutyl ether (MTBE) and nitrate, also were detected in the study well, although all were at concentrations at least an order of magnitude less than established drinking-water standards, where such
The Rio Grande aquifer system in New Mexico consists of a series of basins located along a generally north-south-trending zone called the Rio Grande Rift. Here, tectonic forces in the past forced the crust to begin to pull apart, creating downwardfaulted basins flanked by mountains. Over time, the basins gradually filled with alluvial sediments. Albuquerque is within the Middle Rio Grande Basin in central New Mexico. Sediments consisting of sand, silt, gravel, and clay in varying amounts have filled the basin to a maximum thickness of about 15,000 feet. The public-supply well selected for study is screened from 351 to 1,179 feet below land surface. Like most public-supply and commercial wells in the Albuquerque area, it draws water from the part of the alluvial fill known as the Santa Fe Group.

In the Middle Rio Grande Basin, most water has historically entered, or recharged, the Rio Grande aquifer system as downward seepage from the Rio Grande and its tributaries (Plummer and others, 2004) or as infiltration along the mountain fronts, where runoff of precipitation over relatively impermeable bedrock first encounters permeable basin-fill sediments. Some water also flows from the subsurface bedrock into the alluvial deposits through the sides of the filled basin. Since about the 1930s, manmade sources of recharge have been added, and directions of groundwater flow near Albuquerque have been greatly altered by human activities. The modern direction of groundwater flow on the east side of the Rio Grande is from the river corridor toward the public-supply wells centered primarily in the eastern part of Albuquerque, where large groundwater withdrawals have created a water-level depression.

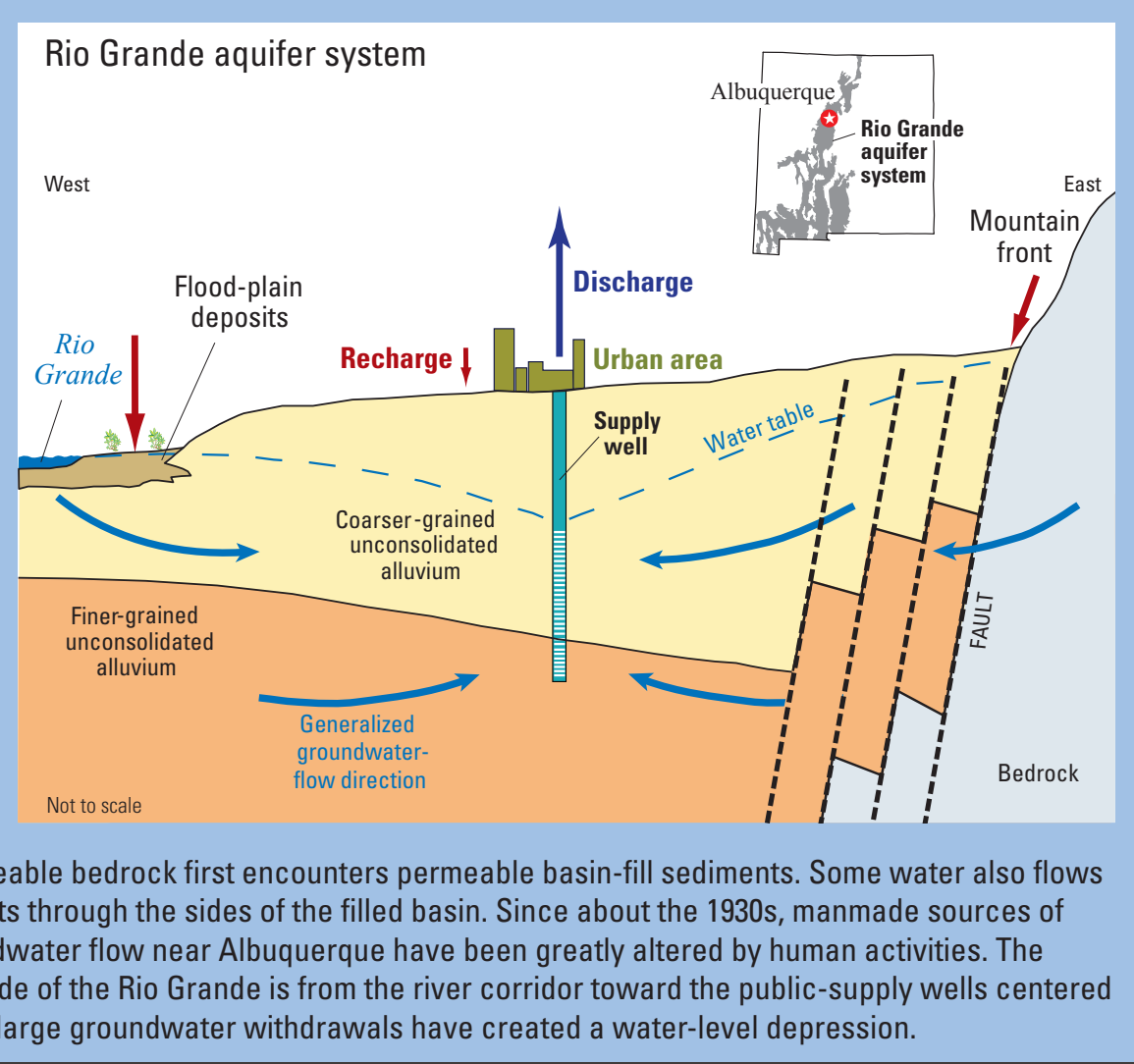

Fact Sheet 2012-3138 December 2012 


\section{Study Design}

As a first phase of study in this area, a computer model of groundwater flow was constructed at a regional scale covering much of the Middle Rio Grande Basin (4,819 square miles) to estimate the "100-year zone of contribution" to the public-supply well selected for study (fig. 1) and also traveltimes from recharge areas to this and other nearby public-supply wells (Bexfield and others, 2011). The 100-year zone of contribution is the three-dimensional volume of the aquifer material through which groundwater flows for the century prior to its eventual discharge at the study well. After the regional model was developed, a network of 9 existing monitoring wells was augmented by 13 additional wells. Most of the monitoring wells were "nested," meaning that multiple monitoring wells tapping different depths in the aquifer were installed within a single borehole. The new monitoring wells were installed at four locations in or near the simulated 100 -year zone of contribution to the study well to collect data on groundwater flow and geochemistry along likely paths of groundwater flow to the well. Water samples were collected from 22 monitoring wells and the 3 public-supply wells shown in figure 1 during June 2007 through May 2009 and analyzed for naturally occurring contaminants (such as radon, uranium, and arsenic) and anthropogenic contaminants (such as volatile organic compounds and nutrients). Analyses for other water-quality constituents (such as major ions, dissolved organic carbon, age-dating tracers, and selected stable isotopes) were done to improve understanding of sources of water and reactions affecting the chemical composition of groundwater.

To determine where water enters the screened interval of the study well, flow of water through the wellbore was measured during both pumping and nonpumping conditions. Similarly, water samples were collected from the study well at various depths while it was being pumped to determine where contaminants enter the well. By using these data, a more detailed, local-scale (9.3 square miles) computer model of groundwater flow and transport to the study well was constructed (Heywood, in press). The local model simulates a 108-year period to evaluate (1) changes in groundwater flow over time, (2) mixing of water of different ages within the groundwater-flow system, (3) changes in sources of water to the study well with seasonal changes in pumping rates, and (4) likely transport pathways and release times for anthropogenic contaminants that have been transported to monitoring and public-supply wells from known sources.

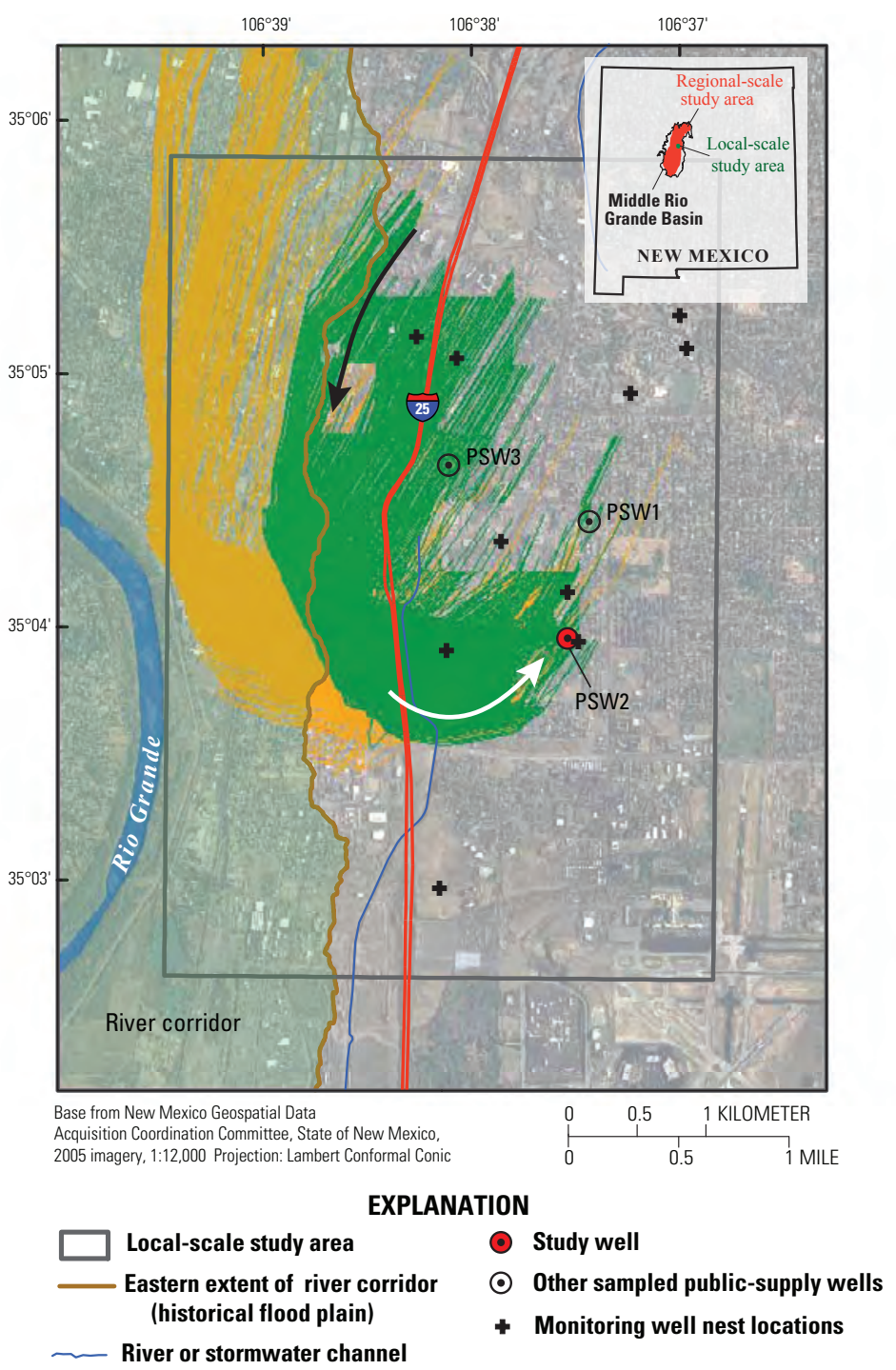

Figure 1. The orange and green lines shown on the map represent two possible sets of flowpaths followed by water traveling through the aquifer system to the study well in eastern Albuquerque, based on two different assumptions about water-transmitting properties of the aquifer. The lines indicate the path traveled in the 100 years prior to reaching the well, as estimated by a computer model simulating regional groundwater flow, and show that the direction of groundwater flow in the area has changed from predevelopment (black arrow) to modern times (white arrow). standards exist. TCE is a widely used solvent, and MTBE is a gasoline additive; documented releases of both chemicals have occurred in the urban area near the study well. Nitrate can be introduced by sewage sources in the Albuquerque area, although natural soil sources also are common in this area.

Overall, the study findings point to four primary influences on the movement and (or) fate of contaminants and the vulnerability of the public-supply well in Albuquerque: (1) groundwater age (how long ago water entered, or recharged, the aquifer), (2) groundwater development (introduction of manmade recharge and discharge sources), (3) natural geochemical conditions of the aquifer, and (4) seasonal pumping stresses. Study findings are intended to help water managers, drinkingwater suppliers, policymakers, and scientists better understand how and why contamination of public-supply wells occurs and whether water quality may improve or degrade. Additionally, computer models developed for the study may be used to evaluate various pumping, resource-development, and land-management scenarios.

\section{Mixing of Young Water with Older Water Increases Vulnerability of Well to Manmade Contaminants}

"Groundwater age" refers to the elapsed time since water entered an aquifer at the water table. The age of groundwater older than 1,000 years was evaluated by using concentrations of the isotope carbon-14 $\left({ }^{14} \mathrm{C}\right)$. To assess the presence of recently recharged water, concentrations of the age tracer tritium were primarily used. Concentrations of tritium in recharge waters increased substantially in the 1950s and 1960s as a result of nuclear weapons testing. 
For the current study, groundwater having a tritium concentration above 0.3 tritium units (TU) was considered to contain a component of young (post1950) recharge, whereas water with a tritium concentration below $0.3 \mathrm{TU}$ was assumed to be native groundwater largely unaffected by young recharge.

Analysis of age tracers indicates that groundwater from most sampled wells in the local study area is predominantly old (pre-1950) water. Native water had ${ }^{14} \mathrm{C}$ ages ranging from 6,500 years in some shallow monitoring wells (with screen midpoints within 60 feet of the water table) to more than 18,000 years old in deep monitoring wells (with screen midpoints more than 607 feet below the water table). Stable-isotope data indicate that the source of the native water was recharge from the Rio Grande. Most of this recharge likely occurred several miles to the north in the basin rather than near the local study area (Bexfield and others, 2011).

In the Middle Rio Grande Basin, the youngest groundwater is expected to be found near the known sources of water infiltrating from land surface - the Rio Grande and the mountain front (fig. 2A). Because potential evapotranspiration (more than 51.2 inches per year) substantially exceeds the average rate of precipitation (8.7 inches per year), it has long been assumed that precipitation over most of the basin evaporates or is transpired by plants long before it infiltrates to water table, which is tens to hundreds of feet below land surface over much of the basin. Therefore, recently recharged groundwater is not expected to be found near the water table in most of the areas between the river and the mountain front. However, the presence of tritium at concentrations greater than 0.3 TU in samples from many, but not all, of the shallow and intermediate monitoring wells (with screen midpoints between 89 and 261 feet below the water table) means that these samples contained a fraction of post-1950 water in addition to a large component of water that was thousands of years old. Shallow-well samples containing tritium were estimated to consist of 14 to 36 percent young water. Samples from some intermediate wells consisted of an even greater fraction of young water - up to 46 percent. Groundwater from two of the three publicsupply wells sampled (including the study well) had a young fraction ranging from 3 to 11 percent. Deep groundwater samples and the third public-supply well (PSW3, fig. 1) were devoid of young water.

Thus, age-tracer data from the study area indicate that recent recharge is reaching the aquifer across broad areas beneath Albuquerque, is migrating from shallow to intermediate depths of the aquifer (depths as great as 245 feet below the water table), and is traveling to some (but not all) of the public-supply wells. The movement of young water to publicsupply wells is of concern because young groundwater is much more likely to have accumulated manmade contaminants during the recharge process compared to old groundwater that recharged the aquifer thousands of years ago. The three major public-supply wells in the study area produce a large proportion of old groundwater ( 89 percent or greater) that has the potential to substantially dilute the anthropogenic contaminants that may be present in the young fraction; however, this old water can add contaminants that occur naturally within the aquifer, because old water from the deep zone of the aquifer is associated with elevated arsenic concentrations (exceeding the 10- $\mu \mathrm{g} / \mathrm{L} \mathrm{MCL}$ ).

\section{Groundwater Development Draws Anthropogenic Contaminants Downward Into the Production Zone of the Aquifer}

Chemical data provide clues as to the source of the young water. Stable isotopes of hydrogen and oxygen indicate that, unlike most groundwater in the study area, the young fraction of shallow water did not typically originate as seepage from the Rio Grande. Although the exact source and mechanism of recent recharge is not clear, it appears to be associated largely with human activities in urban areas for the following reasons: (1) Most shallow and intermediate monitoring wells with tritium concentrations greater than 0.3 TU also contained manmade volatile organic compounds (VOCs) (primarily the industrial solvents perchlorethylene, TCE, or their degradation products at concentrations below the MCL), whereas the deep, old groundwater did not. (2) At least four of the six shallow water samples with a young component of water contained chloroform, a byproduct of drinking-water chlorination. The presence of a chlorination byproduct indicates that the recharge results at least in part from infiltration of chlorinated municipal-supply water.

The effect of manmade recharge sources and human water withdrawals on groundwater flow in the alluvial aquifer was initially examined by using a regional computer model of groundwater flow

(Bexfield and others, 2011). The model simulates, from 1900 through 2008, both natural and manmade sources of recharge, as well as changes in groundwater withdrawals over time, based on available well records. Observed and simulated water levels indicate that the natural, predevelopment (pre-1930s) direction of groundwater flow in the eastern Middle Rio Grande Basin was from the northnortheast to the south-southwest, toward the Rio Grande (fig. 1). Groundwater was recharged from the Rio Grande and its tributaries and along the mountain front and flowed downvalley beneath the river (fig. 2A). Nearly all groundwater exited, or discharged, the system by way of evapotranspiration in the river corridor. Figure $2 B$ shows how new, manmade sources of recharge and discharge have greatly altered groundwater flow and the regional groundwater budget. Flow has been redirected from the river corridor toward wells to the east, and horizontal and vertical hydraulic gradients have steepened, creating an increased downward component of flow. Water levels from predevelopment through 2002 have likely declined by 20 to 120 feet across much of the Albuquerque area (Bexfield and Anderholm, 2002).

The mixing of young, often VOCcontaminated water from manmade recharge sources with older, native groundwater in eastern Albuquerque was investigated in more detail by use of a local-scale groundwater-flow model coupled to the regional model and a corresponding local-scale solute-transport model (Heywood, in press). Local-scale study boundaries are shown in figure 1 . Additional sources of urban recharge were simulated at this local scale that are not shown in figure $2 B$. These sources include municipal waterline and sewerline leakage (the areal extent of which changed over time as Albuquerque grew and the service area increased), infiltration from constructed ponds and watering of turf areas, and seepage from a stormwater diversion channel that is 
unlined in places, allowing leakage from the channel to the groundwater system.

Local-scale simulations show that recent recharge from urban sources is pulled from the water table to intermediate zones of the aquifer when pumping stress is applied by publicsupply wells screened at intermediate and (or) greater depths (fig. $3 A$ ).

Downward flow is nonuniform, because the young water travels preferentially (in larger volumes and at faster rates) through interconnected lenses of coarse sediments. This may explain why young groundwater was found beneath older groundwater at some locations in the study area. Such age inversions could also be the result of direct migration of young water down wellbores screened across large intervals of the aquifer (or down the gravel-filled annular space around such wells) that enables water and contaminants to rapidly bypass normal transport pathways through interconnected pore spaces in the aquifer.

Transport simulations and chemical data show that young water reaching the intermediate zone is mixed with old, native water. Once in the intermediate zone, this mixed water is transported laterally over relatively large distances to public-supply wells. Samples collected from various depths in the study well while it was being pumped indicate that the largest fraction of young groundwater and trace amounts of TCE enter the supply well at depths between 495 and 577 feet below land surface, corresponding to a particularly coarsegrained layer within the intermediate zone of the aquifer.

\section{Natural Geochemical Conditions in the Aquifer Affect the Fate of Contaminants}

Geochemical conditions such as $\mathrm{pH}$ of groundwater control whether specific contaminants are attenuated or mobilized in the subsurface. In the local study area, $\mathrm{pH}$ generally increases with depth in the intermediate and deep zones of the aquifer. Water at depth has been in contact with aquifer sediments for a long time (more than 18,000 years in the deep zone of the aquifer). Greater contact time allows greater dissolution of minerals from the aquifer sediments, and these dissolution reactions tend to increase $\mathrm{pH}$ in groundwater. Above a pH of about 7, arsenic (present primarily in the form
West

\section{A. Predevelopment conditions}

Total flow, 42 billion gallons per year
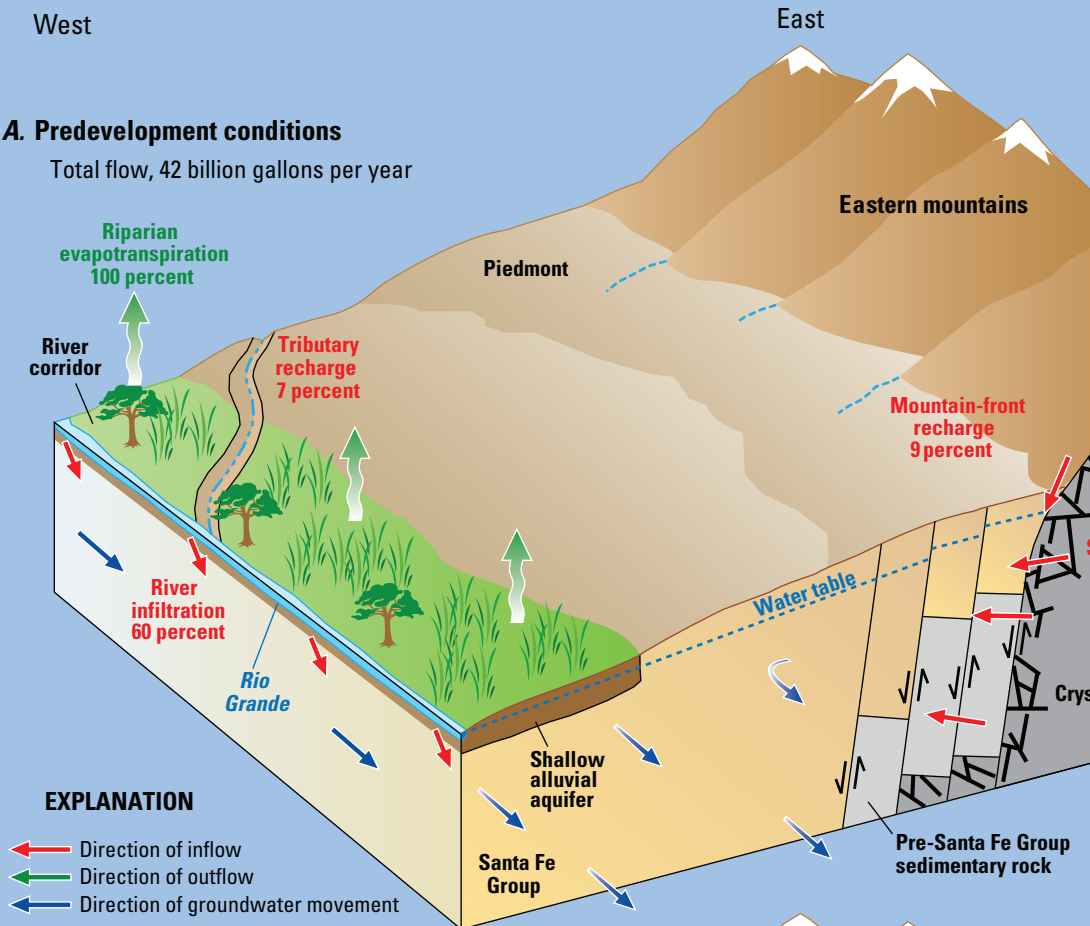

Eastern mountains

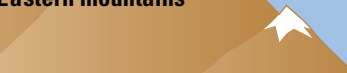

B. Modern conditions

Total flow, 187 billion gallons per year

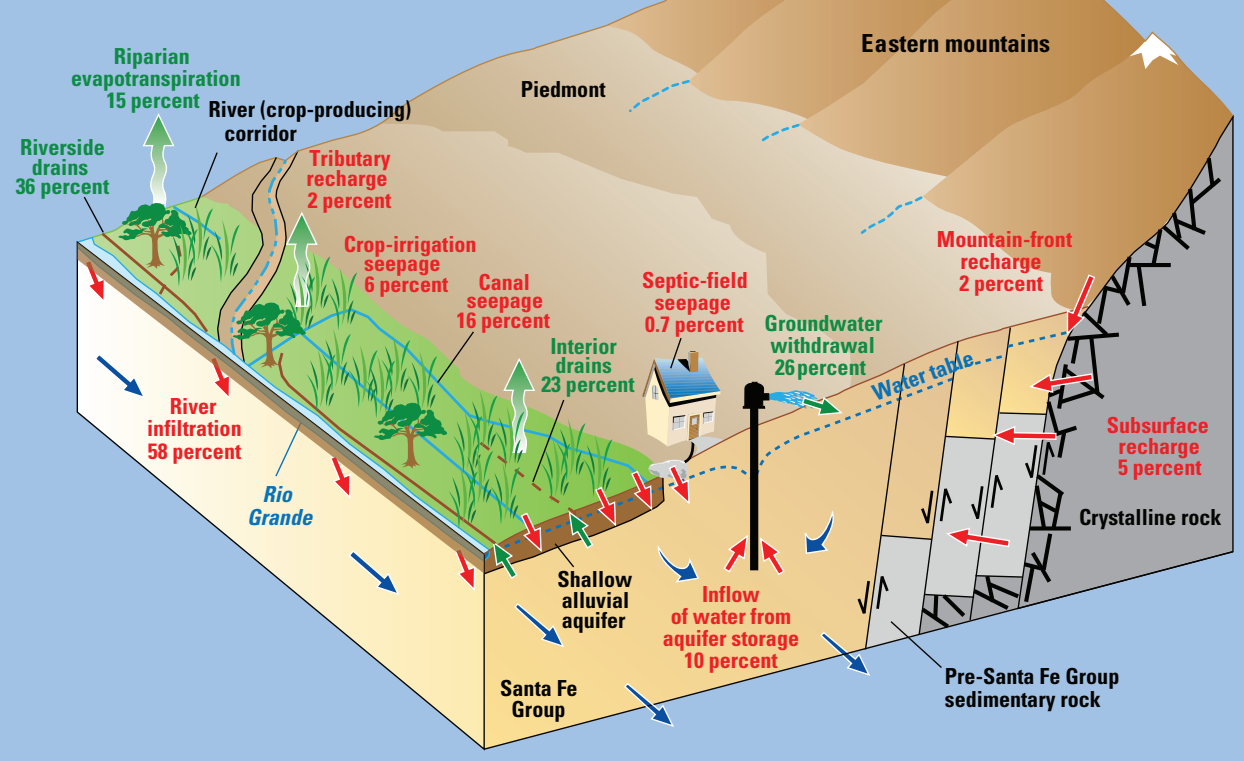

Figure 2. As population in the Albuquerque area has increased over the last 100 years, the addition of manmade features has greatly modified how groundwater enters and leaves the system. New manmade sources of recharge include an extensive network of irrigation canals developed in the early to mid-1900s that diverts water from the upstream Rio Grande and distributes the water to crops planted along the river. Residential development began by the 1930s, and today septic system leachfields contribute recharge to the groundwater system in unsewered areas of the basin. In urban areas, leaking water and sewer pipes are an additional source of recharge (not shown in figure). New sources of discharge include groundwater withdrawals from public-supply wells, which increased substantially beginning in the 1950s. In the river corridor, groundwater drains (riverside drains and interior agricultural drains) have been constructed to lower the water table beneath crops. The water captured by the drains is discharged to the Rio Grande. 

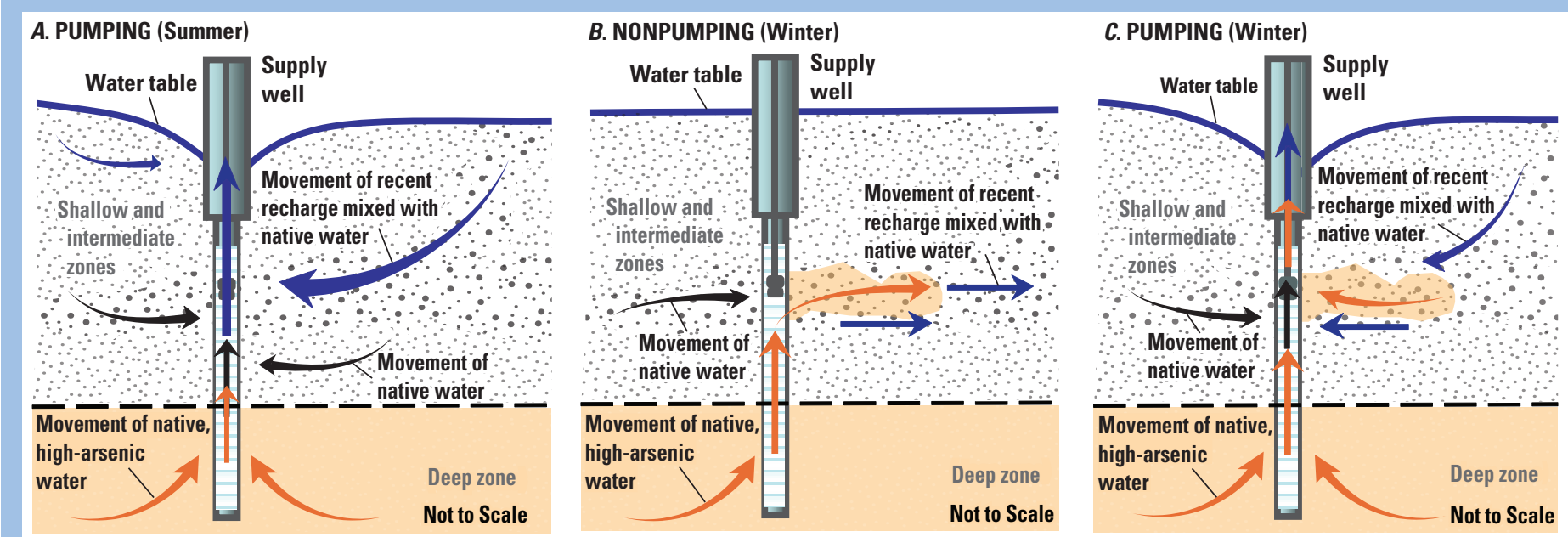

Figure 3. Water produced by the public-supply well is a mixture of native (old) water, high-arsenic water from the deep zone of the aquifer, and recent recharge from urban sources that can be contaminated with VOCs. The proportion of these three types of water entering the well changes with differing seasonal pumping rates. $(A)$ During summer when the pump is on for long periods, recent recharge near the water table mixes with old, native water and is pulled steadily downward to the intermediate zone of the aquifer and to the public-supply well. $(B)$ During winter when the pump is off for several consecutive hours, high-arsenic water travels up the well from the deep zone and exits into the intermediate zone of the aquifer. $(C)$ When the pump is activated in the winter (for a relatively short time each day), some of the leaked, high-arsenic water is recaptured by the well. Having water with elevated arsenic concentrations simultaneously enter the well from both the intermediate and deep zones of the aquifer results in a larger proportion of high-arsenic water produced in the winter than in the summer.

of arsenate) is released from iron oxide coatings on sediments and dissolves into the deep groundwater. The amount of arsenic naturally present in the aquifer sediments also increases below a depth of 820 feet in the vicinity of the supply well. Experiments on sediment cores found that, although some arsenic can be released from aquifer sediments to groundwater at all depths, as much as 10 times more arsenic can be released from the deepest sediment samples. Concentrations of arsenic exceeded the MCL of $10 \mu \mathrm{g} / \mathrm{L}$ in water from two deep wells, from one intermediate well, and from two supply wells (PSW3 and the study well).

\section{Operation of the Public-Supply Well Affects Drinking Water Quality}

Multiple lines of evidence indicate that seasonal changes in the pumping schedule of the study well affect the age and the quality of water produced by the well. Continuous water-level measurements in a monitoring well nest about 100 feet from the study well show that pumping of the study well affects vertical direction of flow in the nearby aquifer: when the pump is off, flow is upward throughout the studied thickness of the aquifer; when the pump is on, flow is downward from the shallow zone to the intermediate zone of the aquifer. Pumping for long durations is common in the summer, when water demand is high. Computer simulations show that increased pumping during the summer causes significant volumes of relatively young water to flow downward from the shallow to the intermediate zone of the aquifer (fig. $3 A$ ). Chemical and age-tracer data from the study well confirm that this downward flow of young water causes an increase in VOC detections (including TCE) in the summer, corresponding to a higher fraction of young water (about 11 percent) produced by the well in the summer than in the winter months. Conversely, arsenic concentrations are lower in the summer (generally less than or equal to $12 \mu \mathrm{g} / \mathrm{L}$ ) than in the winter because of a correspondingly lower fraction of old water being withdrawn from deeper parts of the aquifer (below 820 feet), where arsenic concentrations are particularly high.

In the winter, water demand is lower and the study-well pump typically is idle for several hours each day. Measurements of flow within the wellbore of the study well under nonpumping conditions indicate that the well effectively acts as a conduit for flow of groundwater-as much as 200 gallons per minute - from deep to intermediate parts of the aquifer when the pump is off. Measurements show that water primarily enters the wellbore from the aquifer below a depth of about 856 feet (from the high-arsenic part of the deep zone) and then flows out of the well into the intermediate zone of the aquifer (fig. $3 B$ ).

When the study well is pumped for relatively short periods of time in the winter, the downward hydraulic gradient and the downward flow of shallow water occurs but is less than that observed during the summer. Water-quality data indicate that arsenic concentrations in water produced by the well can be higher when the pump is initially turned on than after several hours of pumping, suggesting that at least some of the high-arsenic water that migrated upward through the wellbore is stored near the well in the intermediate zone of the aquifer and is drawn back into the well once pumping resumes (fig. 3C). Computer simulation of groundwater flow to the well in the winter reveals that a smaller fraction of young water is produced by the well in the winter than in the summer, and a correspondingly greater fraction of old, deep water is produced. (Mixing calculations based on age-tracer concentrations estimate about 6 percent of the water produced in winter is young, compared to 11 percent in the summer.) This mix of water results in higher arsenic concentrations (commonly more than $12 \mu \mathrm{g} / \mathrm{L}$ ) in water produced in the winter than in the summer and a general absence of VOCs in the water produced by the study well in the winter. 


\section{Implications for Protection of Drinking-} Water Quality

The screened interval of a publicsupply well affects its vulnerability to arsenic contamination. Eliminating deeper screened intervals in areas of the basin where arsenic concentrations are elevated at depth could reduce arsenic concentrations from supply wells both directly (by not pumping from higher-arsenic zones) and indirectly (by eliminating the potential for migration of high-arsenic water through wellbores into shallower parts of the aquifer).

VOCs such as TCE can travel rapidly downward to the intermediate zone of the aquifer and can be transported relatively long distances from the source of release. Urban sources of recharge (such as leaking water and sewer pipes, constructed ponds, turf irrigation, and unlined stormwater canals) cause substantial quantities of water to infiltrate to the water table even in the semi-arid climate of Albuquerque. Supply-well pumping enhances migration of this urban recharge containing low levels of VOCs both downward to the depth tapped by public-supply wells and horizontally. These findings indicate that source water protection (which guards against chemical releases at or near land surface) can favorably affect the quality of drinking water, even in areas where climate and hydrogeology have resulted in predominantly old groundwater.

The presence of long-screened wells in an aquifer with a significant vertical component of groundwater flow is likely to alter the movement of water and contaminants through the aquifer even when those wells are not pumping.

Two recent studies in two different aquifer systems have documented the flow of water through long-screened wells under nonpumping conditions. The study discussed herein measured the upward flow of water through a well from a high-arsenic, deep zone of the Rio Grande aquifer system to a shallower zone that generally has arsenic concentrations below the drinking-water standard. In contrast, Jurgens and others (2008) found that a long-screened well in the Central Valley aquifer system near Modesto, California, allows shallow water with elevated uranium and nitrate concentrations to migrate down the well and into the relatively pristine, deep zone of the aquifer when the well is not being pumped. Knowledge of vertical flow directions in the vicinity of a longscreened well (under both pumping and nonpumping conditions), coupled with understanding of variations in contaminant concentrations with depth in the aquifer, can help water managers predict the positive or negative effect that wellbore flow will have on water quality and can lead to development and testing of strategies to mitigate contamination (such as changes in pumping schedules, development of devices to inhibit wellbore flow when the pump is off, and eliminating intervals of well screens that are in zones of undesirable water quality).

\section{References}

Bexfield, L.M., and Anderholm, S.K., 2002, Estimated water-level declines in the Santa Fe Group aquifer system in the Albuquerque area, central New Mexico, predevelopment to 2002: U.S. Geological Survey Water-Resources Investigations Report 02-4233, 1 sheet.

Bexfield, L.M., Heywood, C.E., Kauffman, L.J., Rattray, G.W., and Vogler, E.T., 2011, Hydrogeologic setting and groundwater flow simulation of the Middle Rio Grande Basin regional study area, New Mexico, section 2 of Eberts, S.M., ed., Hydrologic settings and groundwater-flow simulations for regional investigations of the transport of anthropogenic and natural contaminants to public-supply wellsInvestigations begun in 2004: U.S. Geological Survey Professional Paper 1737-B, p. 2-1 to 2-61.
Bexfield, L.M., Jurgens, B.C., Crilley, D.M., and Christenson, S.C., 2012, Hydrogeology, water chemistry, and transport processes in the zone of contribution of a public-supply well in Albuquerque, New Mexico, 2007-9: U.S. Geological Survey Scientific Investigations Report 2011-5182, 114 p.

Bexfield, L.M., and Plummer, L.N., 2003, Occurrence of arsenic in ground water of the Middle Rio Grande Basin, central New Mexico, chap. 11 of Welch, A.H., and Stollenwerk, K.G., eds. Arsenic in ground waterGeochemistry and occurrence: Boston, Kluwer Academic Publishers, p. 295-327.

Heywood, C.E., in press, Simulations of groundwater flow, transport, and age in Albuquerque, New Mexico, for a study of Transport of Anthropogenic and Natural Contaminants (TANC) to public-supply wells: U.S. Geological Survey Scientific Investigations Report 2012-5242.

Jurgens, B.C., Burow, K.R., Dalgish, B.A., and Shelton, J.L., 2008, Hydrogeology, water chemistry, and factors affecting the transport of contaminants in the zone of contribution of a public-supply well in Modesto, eastern San Joaquin Valley, California: U.S. Geological Survey Scientific Investigations Report 2008$5156,78 \mathrm{p}$.

Plummer, L.N., Bexfield, L.M., Anderholm, S.K., Sanford, W.E., and Busenberg, E., 2004, Geochemical characterization of ground-water flow in the Santa Fe Group aquifer system, Middle Rio Grande Basin, New Mexico: U.S. Geological Survey Water-Resources Investigations Report 03-4131, $395 \mathrm{p}$.

By Martha L. Jagucki, Laura M. Bexfield, Charles E. Heywood, and Sandra M. Eberts

\section{Contacts}

Sandra Eberts, Team Leader, (614) 430-7740, smeberts@usgs.gov; Charles Heywood, Groundwater Modeling, (970) 626-9840, cheywood@usgs.gov; Laura Bexfield, Geochemistry, (505) 830-7972, bexfield@usgs.gov

For more information on the NAWQA topical study of contaminant transport to public-supply wells (TANC), see http://water.usgs.gov/nawqa/ 